This is an Author's Accepted Manuscript of an article published in Security Dialogue, Volume 44, Number 1, 2013, pp.53-71 (copy right Sage).

The published version may be available FREE at: http://sdi.sagepub.com/content/44/1/53.full.pdf

[Note for citations: The pagination below matches that of the printed version of the article.]

\title{
United States, PMSCs and the State Monopoly on Violence: Leading the Way towards Norm Change
}

\author{
Elke Krahmann
}

Department of Politics and History, Brunel University

\begin{abstract}
The proliferation of private military and security companies (PMSCs) in Iraq and Afghanistan has raised many questions regarding the use of armed force by private contractors. This article addresses the question of whether the increased acceptance of PMSCs indicates a transformation of the international norm regarding the state monopoly on the legitimate use of armed force. Drawing on theoretical approaches to the analysis of norm change, the article employs four measures to investigate possible changes in the strength and meaning of this norm: modifications in state behaviour, state responses to norm violation, the promulgation of varying interpretations of the norm in national and international laws and regulations, and changes in norm discourse. Based on an analysis of empirical evidence from the United States of America and its allies, the article concludes that these measures suggest that the USA is leading the way towards a transformation of the international norm of the state monopoly on violence, involving a revised meaning. Although this understanding has not yet been formally implemented in international law, it has allowed a growing number of countries to tolerate, accept or legalize the use of armed force by PMSCs in the international arena.
\end{abstract}

\section{Keywords}

private security, PMSC, state monopoly on violence, norm change, United States

\section{Introduction}

The proliferation of private military and security companies (PMSCs) in the interventions in Iraq and Afghanistan and the seeming impunity of firms such as Blackwater ${ }^{1}$ have raised many questions regarding the legitimacy and legality of the use of armed force by private contractors (Leander, 2010; Chesterman and Lehnardt, 2007). The Montreux Document on Pertinent International Legal Obligations and Good Practices for States related to Operations of Private Military and Security Companies during Armed Conflict, signed by seventeen states in September 2008, 
one year after Blackwater contractors killed 17 innocent civilians in a shootout on the streets of Baghdad, has been considered a key step towards addressing these issues. ${ }^{2}$ The Montreux Document contains two parts. Part one reiterates the obligations of states under international humanitarian law and human rights law; part two proposes a set of voluntary good practices, drawn from the codes of conducts of PMSCs and security industry associations. Disregarding the issue of whether the Montreux Document will be effective in curtailing the impunity of PMSCs (Cockayne, 2008), this article takes the document as a point of departure for raising another question: Are we witnessing a transformation of the international norm of the state monopoly on the legitimate use of violence?

The origins of this question lie in the implicit tension between divergent interpretations of the norm of the state monopoly on violence in international affairs that inform the two parts of the document. The first part rests on the twentieth-century understanding of the norm, embodied in international laws and conventions. In this understanding, the norm prescribes that only states and their armed forces may legitimately and legally exercise coercive force for purposes other than self-defence. By contrast, the second part appears to legalize and legitimize the use of armed force by incorporated companies providing international military and security services through the document's recognition of the legality of these firms and its advocacy of a self-regulation of the industry (Cockayne, 2008: 404).

The potential consequences of a shift from the first interpretation of the norm to the second are serious and far ranging. Widespread international acceptance of the use of military force by PMSCs would allow the industry to operate within a legal grey-zone created by the focus of existing laws of war on the actions of states. In addition, the legalization and legitimization of the commercial supply of armed force would create a new market in which collective violence and conflicts may be fuelled by the profit motives of PMSCs. In time, the normalization of incorporated military force may even lead to the return of commercial armies like the Medieval condottieri or the sixteenth century landsknechte (Percy, 2007a; Thomson, 1994). That these scenarios may seem improbable or even ludicrous attests to the widespread acceptance of the norm of the state monopoly on violence. However, as this article will illustrate, several developments suggest that the interpretation of the norm of the state monopoly on violence is changing. Already in the 1990s PMSCs such as Sandline International and Executive Outcomes intervened in civil wars with combat forces. A decade later then British Foreign Minister Jack Straw suggested that "a strong and reputable private military sector might have a role in enabling the UN to respond more rapidly and effectively in crises" (BBC, 2002).

This article argues that the employment of armed PMSCs by governmental and nongovernmental actors, and the formal acceptance of these practices in national and international legal or paralegal documents and regulations, such as the Montreux Document, suggests not only a transformation in the behaviour of select states, but also in the international norm of the state monopoly on the legitimate use of violence. To do so, the first part discusses the definition and impact of norms in international relations, theoretical approaches to the analysis of norm change and the problems of measuring it. The second part outlines the historical evolution of the norm of the state monopoly on violence before the third part examines the empirical evidence for a transformation of the norm, focussing on the USA and its allies.

\section{Norms and their Impact}

What are norms and why do they matter in international relations? There are numerous definitions of norms, ranging from "appropriate standards of behaviour" (Finnemore \& Sikkink, 1998: 891) to the claim that "a norm exists in a given social setting to the extent that individuals usually act in a certain way and are often punished when seen not to be acting in this way" (Axelrod, 1986: 1097). 
Most conceptualizations of norms share four characteristics. First, a norm pertains to collective social expectations (Raymond, 1997: 215). A single individual can have ideals, beliefs and principles, only a group or society can establish norms. Second, a norm concerns generalized standards of behaviour (Goertz \& Diehl, 1992: 636-7; Raymond, 1997: 217). Although actions may not always (need to) conform to a norm, e.g. if there are conflicting norms, the expectation exists that a norm should be regularly adhered to. In order to ensure this, communities often sanction failure to abide by a norm (Axelrod 1986: 1097). Third, a norm is normative (Goertz \& Diehl, 1992: 638-9; Raymond, 1997: 217-18; Björkdahl, 2002: 14-15; Florini, 1996: 364-5). It prescribes how individuals or collectives ought to act because of ethical or moral concerns. A norm thus differs from rules or standards, which merely prescribe regularized behaviour, such as stopping at a red traffic light. Fourth, norms may vary in the strength of their impact on behaviour (Axelrod, 1986: 1097; Nadelmann, 1990). Several factors can limit the power of a norm: frequent violation, the failure of the community to punish non-compliance, the size of the community that subscribes to a norm, and the range of actions that are considered to be regulated by a norm. In the following, the transformation, development or evolution of norms thus refers to long-term variations in the strength and understanding of a norm.

The strength and potential influence of international norms rests on several factors. International norms act as intervening variables between interests and actions by changing an agent's incentive structures through sanctions and rewards (Krasner 1982; Price 2003). Formal monitoring and sanctioning mechanisms, ranging from material sanction such as embargoes to social pressure such as being "labelled as deviants", enhance punishment for non-compliance (Nadelmann, 1990: 479; Klotz 1996). Material sanctions can be enforced through international prohibition regimes, laws and conventions such as the Nuclear Non-proliferation Regime. Social pressure includes the impact of transnational political movements and organizations such as Amnesty International. Rewards also play a major role in facilitating international norm compliance. The most basic reward is membership within the community that subscribes to a particular norm (Anderson, 2000: 171). European Union accession for instance is dependent on the implementation of several norms, including democracy and human rights. Membership can also provide material gains and access to international decision-making processes.

In addition, norms serve as constitutive variables that influence identities and interests (Klotz 1995; Cortell \& Davis, Jr. 1996). As Amitai Etzioni (2000: 163) writes, "social norms help people form (and re-form) the self, by profoundly influencing their identities, their worldviews, their views of themselves, the projects they undertake, and thus the people they seek to become". The same applies to collectives such as the societies of states. National identities in part derive from the norms that societies and their governments believe in. Certain normative standards are internalized to the extent that interests are defined by and through them. US government policies towards apartheid in South Africa, for instance, changed when pressure groups succeeded in linking the norm of racial equality to the norm of civil rights, which is central to US national identity (Klotz, 1995).

At the same time as norms influence the self-images and behaviour of social and political actors, these actors, their discourses and interactions contribute to the development and revision of international norms. The question of whether norms or actors play a more important role in defining international relations has been discussed in the structure-agency debate (Hollis \& Smith 1991). The study of structures provides insights into the social conditions that influence multiple actors, their interests and their behaviour. Agency-focused analyses help to understand how the motives, strategies and interactions of governments and non-state actors transform structures such as international norms. With regard to the norm of the state monopoly on violence, this article benefits from a combination of both perspectives. The first perspective allows it to 
illustrate how the norm has impacted on the structure of the international system, international law and the resolution of interstate conflicts over the past centuries. The second perspective enables it to investigate how the actions of major countries have contributed to the transformation of the norm by setting important precedents and by changing the discourse on the norm of the state monopoly on violence.

\section{Norm Change and Its Measurement}

Since norms simultaneously influence the behaviour of governments, and are shaped and transformed by this behaviour, norms are always in the process of being (re)defined. The question of how and why norms change has therefore taken a prime place in the analysis of norms. Several complementary theoretical approaches help to explain norm development. They identify a number of factors that contribute to norm emergence and change, and isolate several stages in their evolution.

One factor in the promotion of norms or norm change is the activities of norm entrepreneurs (Finnemore \& Sikkink, 1998; Nadelmann, 1990; Payne, 2001). Norm entrepreneurs contribute to the emergence or change of norm in three stages. At the "norm emergence" stage, norm entrepreneurs attempt to persuade others to adopt new norms. At the "norm cascade" stage, imitation takes a major role as norm entrepreneurs seek to socialize others into the new norms. Finally, "norm internalization" occurs when norms "acquire a taken-for-granted quality are no longer a matter of broad public debate" (Finnemore \& Sikkink, 1998: 895). In addition, a number of structural factors play a role in the evolution of norms (Axelrod, 1986; Florini, 1996; Boyd \& Richerson, 1994; Sandholtz, 2008). They include the "inescapable tension between general norms and specific actions [which] ceaselessly casts up disputes, which in turn generate arguments, which then reshape both rules and conduct" (Sandholz, 2008: 101). Norms can also change because they appear to have lost their utility (Spruyt, 2000: 69-70).

According to the literature, three factors encourage norm transformation or the emergence of a new norm: prominence, precedent and coherence. Prominence regards the ability of a norm to gain acceptance because a significant number or particularly powerful actors support it. Norms spread if "actors see others behaving in a certain way and copy those behaviours" (Florini, 1996: 378). The more actors behave according to a norm, the greater the likelihood that others will emulate them (Paluck, 2009). Applied to the case of the norm of the state monopoly on violence, the disregard or redefinition of the norm by particularly powerful governments such as that of the USA can thus lead to its transformation if other countries follow its example. The more widespread the international use of armed security contractors, the more likely it is that it will be considered normal.

Precedent refers to the fact that a norm has been (re)interpreted and implemented in a particular way before (Sandholz, 2008: 106). If an actor chooses to ignore a norm because it does not serve its interests and because the norm seems to have lost its rationale, this actor sets a precedent (Fitzsimmons, 2009: 9-10). The more influential the actor and the greater the number of similar precedents, the more likely is norm change. For instance, if leading countries employ armed contractors in international interventions and peacekeeping missions or permit the use of armed guards on ships in international waters, their example is likely to influence other governments. Other precedents may include the failure to punish the excessive use of armed force by PMSCs or the formal recognition of the legality of these firms in national laws and regulations.

Finally, coherence or consistency applies to the fit of a norm with other dominant norms (Sandholz, 2008: 107; Payne, 2001: 38-9). The legitimization of PMSCs and their deployment of armed force are thus likely to become a norm if it conforms to the existing normative environment. In the case of private 
security, this may apply to the diffusion of Neoliberal norms such as free trade, individual choice and the scaling down of public services.

While the above suggests that several factors may facilitate a change in the norm of the state monopoly on violence, a key problem affects its empirical analysis: How does one measure norm change? Several elements contribute to this problem. By definition, norms concern ideal standards of behaviour. As a result there is often a differential between a norm and its implementation. A good example is the norm against homicide. Although this norm is shared universally, murder occurs in all societies. In addition, norms do not exist in a vacuum. Often they compete with other norms for predominance. The right to smoke in public, for instance, has been curtailed in some countries due to its conflict with non-smokers' rights to health and safety. The last factor is the mutual constitution of norms and behaviour. Norms influence behaviour, but behaviour also redefines norms. As Sandholz (2008: 101) writes, "Normative structures ... cannot stand still". Actions express norms as much as they (re)define them.

Despite these problems a growing number of scholars have examined the development of norms. They have used four measures to assess the varying strengths and definitions of norms (Goertz \& Diehl, 1992: 642-6; Kacowicz, 2005: 13; Percy, 2007a: 373; Cortell \& Davis, 2000: 69). One measure analyses changes in norm-related behaviour. This indicator is likely to detect norm transformation at an early stage because it does not require the formal recognition of a norm. Moreover, changing behaviour can shape norms. A second approach observes the responses of governments and other actors to the violation of a norm. This method has the advantage that it can measure the erosion of an existing norm as well as the positive impact of a norm. The former involves the toleration of norm violation, the latter its punishment. Since the punishment of norm violations is costly, it is a good indicator of the strength of a norm (Axelrod, 1986: 1100). A third measure investigates the formal promulgation of a norm and the stipulations for its punishment in national and international laws (Axelrod, 1986: 1106). This indicator illustrates the strength of a norm even if behaviour does not always conform to it. Its disadvantage is that some norms are never incorporated into laws and that promulgation occurs usually at the final stage of norm development (Posner \& Rasmusen, 1999: 370). A fourth way of assessing a norm is to examine whether and how actors use it discursively to legitimize particular actions or behaviour. Of specific interest to norm change is here how actors who seek to overcome normative objections "must try to show that the facts are not as they seem to be; or that the rule, properly interpreted, does not cover the conduct in question" (Chayes \& Chayes, 1995: 118, cited in Cortell \& Davis, 2000: 69).

\section{The Norm of the State Monopoly on Violence}

The implications of PMSCs for the state monopoly on the legitimate use of armed force are among the main concerns discussed in political and academic circles, but the norm itself has received little systematic attention (Leander, 2006; Bailes et al., 2007). One explanation may be that Max Weber's often-quoted phrase that the state holds the "monopoly of legitimate physical violence within a certain territory" (Weber, 1994: 310-11) refers to the ideal-type characteristics of the modern state and not an international norm. Existing studies of the consequences of the recent proliferation of PMSCs have therefore focused on the global norm against mercenarism which is formally and explicitly set out in international laws and conventions (Petersohn \& Panke, 2012; Fitzsimmons, 2009; Percy, 2007a; Thomson, 1990). Following the argument of major governments and the industry that PMSCs are not mercenaries these studies have concluded that the proliferation of armed security contractors has not resulted in or been the consequence of a weakening of the mercenary norm. 
Indeed, Percy (2007a: 241) argues that the norm against mercenarism has become "more puritanical" due to the emergence of PMSCs. Taking on the broader and more difficult to assess norm of the state monopoly on violence, this article suggests that the rise of PMSCs has had major implications for international norms.

Specifically, this article contends that the state monopoly on the legitimate use of collective force is an international norm because it meets the four aspects of an international norm outlined in the preceding sections. The norm of the state monopoly on violence pertains to collective social expectations about the use of armed force; it concerns generalized standards of behaviour; it builds on moral and ethical principles; and it has varied in strength and content during the past three centuries. In fact, it may be argued that the state monopoly on violence is a foundational norm that has informed a range of international legal standards, subsuming conventions against mercenarism, privateering, and the recruitment of citizens for foreign military service. The norm of the state monopoly on violence appears to resemble the norm of state sovereignty because it is fundamental to multitude of international laws and rules (Barkin \& Cronin, 1994).

Since its content, normative justifications, institutionalization and impact have evolved significantly during the past centuries, the norm of the state monopoly on the legitimate use of violence is for the purposes of the following analysis best defined as the generalized expectation that sovereign governments or rulers should be the only actors who may legitimately use collective armed force for purposes other than self-defence. The exact beginnings of this international norm are impossible to pinpoint. As Opello and Rosow (2004: 63) write, already the "medieval kings gathered to themselves the instruments of politico-military rule that had been hitherto dispersed among the estates. ... Gradually, the castles of provincial lords were destroyed and the private armies of the nobility were disarmed. The production of battlefield weapons was monopolized in the king's arsenals". Initially, this monopolization was an attempt to eliminate the collective use of force by alternative 'public' authorities such as the church or feudal lords. Commercial suppliers of armed force such as mercenaries, freebooters and privateers were considered legitimate as long as they worked for the king or his vassals (Percy, 2007a: 72). The moral justification for the centralized control of the medieval ruler over collective means of violence rested in semi-religious beliefs that saw him as installed by God (Percy, 2007a: 91). The king "understood himself to be acting for the moral and spiritual well-being of those he ruled" (Opello and Rosow, 2004: 65).

With the emergence of the modern state system the normative ideal of centralized control over violence shifted from the person of the king to the apparatuses of government and its justification changed from the ruler's special status derived from God to the common good (Percy, 2007a: 77). Mercenaries and privateers were brought under the control of states through a variety of mechanisms, including the establishment of permanent relations with their governments. In Italy, citizenship and landownership served to incorporate condottieri into particular states (Percy, 2007a: 86). In Germany, seventeenth century enterprisers such as Wallenstein became agents of the state which "never recruited troops or commanded them outside the control of a sovereign" (Percy, 2007a: 88). In short, between 1600 and 1800 governments and rulers authorized most non-state uses of collective violence (Thomson, 1994: 21).

Despite these developments, governmental control of non-state armed forces was frequently ineffective (Thomson, 1994: 70). In the nineteenth century, most countries therefore stopped sanctioning the private use of violence (Ortiz, 2010: 32). Changing moral beliefs about the state and citizenship undermined simultaneously the legitimacy of the private use of armed force. Percy 
(2007a: 121) observes, "As the concept of citizen duty to the state grew, and as patriotism and nationalism became increasingly seen as desirable and practical for armies, a selfish and financial motivation became morally inappropriate and practically inferior". The nineteenth century thus saw major changes in the practice and interpretation of the norm of the state monopoly on the legitimate use of force. Previously the norm was interpreted as permitting private violence if it was controlled or authorized by a sovereign government. The new understanding was that non-state armed force should be considered illegitimate as a matter of principle and that governments should refrain from permitting the use of violence by private actors. International institutions, including the Paris Declaration Respecting Maritime Law (1856) which proclaimed that "privateering is and remains abolished", increasingly formalized the new interpretation of the norm (Thomson, 1994: 71-75). In addition, numerous countries passed domestic laws against the recruitment or enlistment of their citizens for foreign military service (Thomson, 1994: 80-81; Nossal, 2001: 464-7). The spread of democracy in Europe and North America and the associated moral conviction that only elected governments had the legitimacy to decide on collective uses of force reinforced the new interpretation of the norm (Singer, 2003: 31; Wulf 2007: 7).

Although these laws and principles emerged in the first instance in Europe and North America, in the twentieth century the norm of the state monopoly on violence, understood as the prohibition of private uses of collective force in international affairs, gained formal global recognition (Leibfried et al, 2008; Percy, 2007a). Specifically, the norm provided the basis for the special status of states and national armed forces with regard to national and international security, stipulated in the Kellogg-Briand Pact (1928), the (UN Charter (1945) and the Geneva Conventions (1949), including the Additional Protocol I to the Geneva Conventions (1977) which excludes mercenaries from the benefits of prisoner of war status. The ratification of these treaties and conventions by 193 (UN Charter), 194 (Geneva Conventions) and 171 (Additional Protocol I) states respectively, illustrated the global recognition of the principle of the state monopoly on the legitimate use of armed force in international affairs.

From the 1970s the explicit prohibition of mercenarism in the Organization of Africa Unity/African Union (AU) Convention for the Elimination of Mercenarism in Africa (1977) and the UN Convention against the Recruitment, Use, Financing and Training of Mercenaries (1989, effective since 2001) further formalized the narrow interpretation of the norm. The UN Convention (1989, Art. 5) not only made being a mercenary an offence, but also the recruitment, use, financing and training of mercenaries by sovereign governments, i.e. practices considered legitimate until the nineteenth century. Neither the Geneva Conventions nor the UN and AU Conventions on Mercenarism limited their prohibitions to the use of offensive armed force by private actors. According to these conventions, any direct participation in hostilities by actors other than national armed forces and recognized parties to the conflict was a criminal offence. Moreover, the Geneva Conventions stated that civilian contractors accompanying national militaries in the field would lose their protected status if they engaged in hostilities. The definition of 'direct participation in hostilities' included "denying the adversary the military use of certain objects, equipment and territory" (ICRC, 2009: 48). The ICRC further noted that international humanitarian law defines attacks as "acts of violence against the adversary, [irrespective] whether in offence or in defence" (ICRC, 2009: 49).

Although the two mercenary conventions have been ratified only by 30 (OAU/AU) and 32 (UN) states respectively, there has been widespread adherence to the norm, including by many non-signatory states. Ortiz (2010: 32; also Percy, 2007a: 148) observes, "The last time a European state raised a mercenary army was in 1854, when Britain hired German, Italian, and Swiss mercenaries for the Crimean War". In the twentieth century, foreign fighters were either formally 
integrated into national armed forces, such as the French Legion or the Ghurkas in the British Army, or they were hired by rebel or weak governments that lacked a monopoly on violence in the first instance (Ortiz, 2010: 32-37). When Western governments such as those of the USA and the UK hired civilians or companies to support their militaries in international conflicts they excluded the use of armed force (Ortiz, 2010: 32-37).

\section{PMSCs and Norm Change}

Drawing on the theory of norm change, four measures provide evidence for a renewed transformation of the norm of the state monopoly on violence. First, this section examines changes in the behaviour of major governments with regard to PMSCs and the private use of armed force. It specifically focuses on the USA as a leading country with the ability to act as an international norm entrepreneur and provide important precedents for norm change. However, the following also examines to what degree other governments have imitated US behaviour and policies. Second, this section investigates how the USA and other countries have responded to private military and security contractors who have engaged in the use of armed force, including the killing of civilians. Third, it analyses whether and in how far the growing role of PMSCs in international affairs and their use of violence has become accepted in international laws and conventions. Finally, this section examines how the observed changes in the practices of major governemnts and international organizations have been justified in political and legal discourses.

\section{Practices of International Security}

Changes in the behaviour of governments are often the first step in the emergence or transformation of international norms. However, it is difficult to establish when precedent turns into generalized standards of behaviour. A simple measure would be if a majority of governments has changed their practices. In the case of PMSCs, the evidence suggests that this stage has not been reached yet. Nevertheless, there have been significant modifications in the behaviour of governments in North America and Europe as well as in some developing countries that involve the growing use of private armed force in national and international conflicts. Key precedents for the hire of PMSCs for direct participation in hostilities have been set by the failing governments of Sierra Leone and Angola during the 1990s (Howe 1998; Adams 1999; Francis 1999; Cleaver 2000). Although this practice has not been repeated since and neither country acted as a norm entrepreneur on this issue, in the aftermath of these operations PMSCs have established themselves successfully as the helpmates of governments in international interventions and postconflict environments. In particular, the USA is increasingly hiring PMSCs for military support in international interventions (Avant, 2005; Isenberg, 2008; Singer, 2003). In Iraq and Afghanistan the USA is, according to the Congressional Research Service "relying heavily, apparently for the first time during combat or stability operations, on private firms to supply a wide variety of security services" (Schwartz, 2011: 1). Between 2008 and 2010, the USA's use of armed security contractors has expanded exponentially from 6,000 to 11,030 in Iraq and from 3,184 to 16,398 in Afghanistan (Schwartz, 2010: 10) [Figure 1].

The proliferation of armed guards gains a special significance because, since 2006, Department of Defense (DOD) contractors are expressly "authorized to use deadly force when such force reasonably appears necessary to execute their security mission to protect assets/persons, consistent with the terms and conditions contained in their contract or with their job description and terms of 
Figure 1. US Security Contractors in Afghanistan (Quarterly Figures) ${ }^{3}$

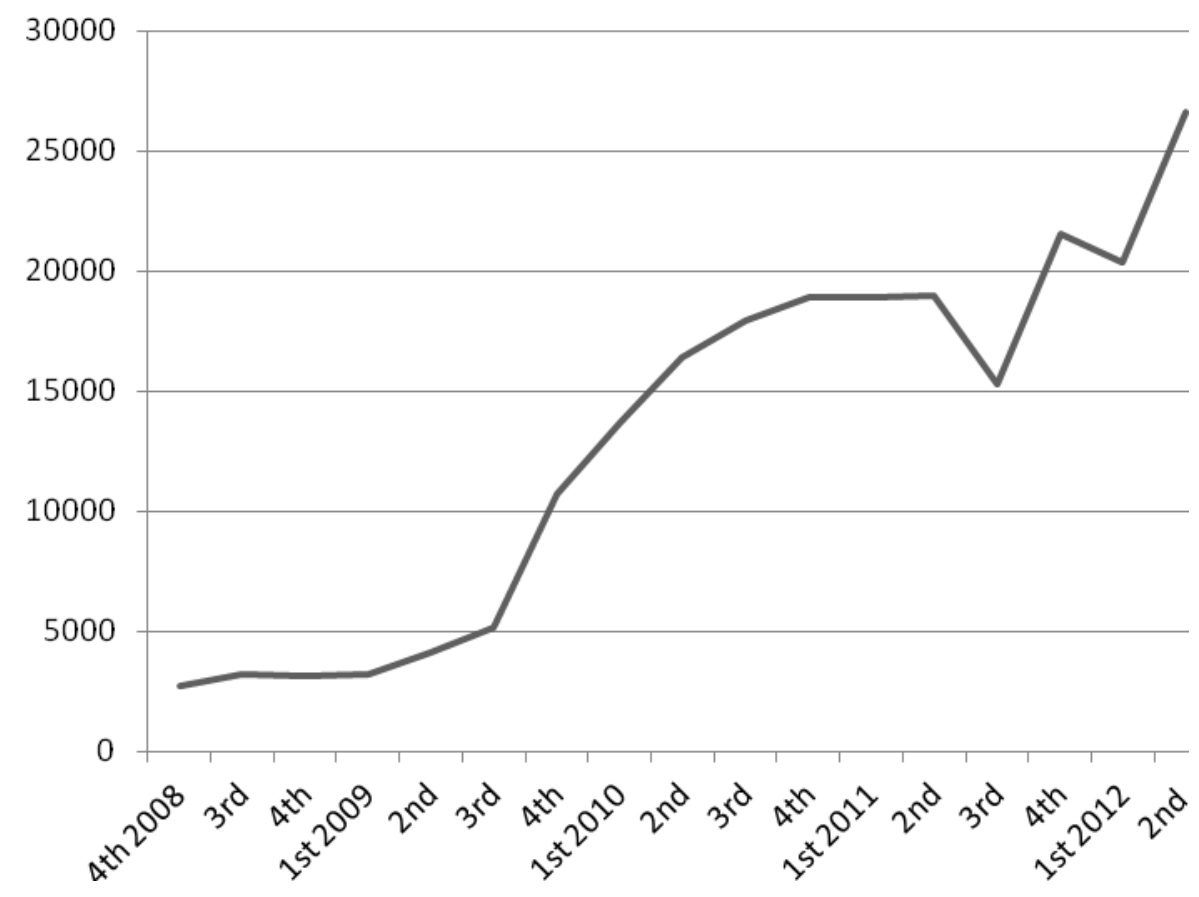

employment" (DOD, 2006: 34826; DFARS, 2009). Moreover, the above figures include only DOD contractors. The total numbers of armed security guards working for the US government were larger still with an estimated 25,000-30,000 in Iraq and 26,000 in Afghanistan (Schwarz, 2010: 3; Filkins and Shane, 2010). In sum, although the USA complied with the understanding of the norm of the state monopoly on violence as prohibiting not only the private use of armed force in international conflicts, but also government authorization of such force during twentieth century, recent developments suggest this has changed in two ways. First, the USA has formally and explicitly permitted its armed contractors to use force for purposes other than self-defence in international operations. Second, the USA is employing armed contractors not only in exceptional or clandestine operations, but massively and openly.

While the USA may be leading in its extensive reliance on armed security guards, a growing number of developed countries in North America and Europe are using security contractors to protect their international military, police and civilian operations (Krahmann \& Friesendorf, 2011a; Leander, 2012 forthcoming). Canada, for instance, hired four PMSCs to secure its ISAF forward operating bases in Kandahar (Moore, 2010). The Netherlands employed private security contractors to guard the outer circle of military installations in Afghanistan (AIV, 2007; Finabel, 2008: 14). Germany contracted 246 Afghan security guards to help safeguard its military bases in Faisabad, Mazar-e Sharif, Kundus and Taloquan (Krahmann \& Friesendorf, 2011: 8, 11). France partially outsourced security and protection for the mainly French 'Camp Warehouse' (Leander, 2012 forthcoming). These policies place security contractors increasingly in the line of fire, accepting that private guards become legitimate targets in a conflict if they protect military installations (UN, 2010: 6). Between 2009 and 
2010, 319 US security contractors were "killed in action" in Afghanistan, compared to 626 US soldiers (Schwartz, 2011: 9).

The USA, NATO, EU and UN contribute to spreading the acceptance of armed PMSCS among allies and member states by hiring these firms for joint military bases and operations (Krahmann \& Friesendorf, 2011a). In Iraq, for instance, companies such as Triple Canopy, Sabre, EOD Technology and SOC-SMG supplied armed guards to the multinational forces through contracts with the Joint Contracting Command in Baghdad. In Afghanistan, NATO's International Stabilization Force (ISAF) employed armed security guards to protect supply convoys on the dangerous route between Kabul and Kandahar where contractors engaged regularly in fights with up to 200 insurgents (Wikileaks, 2009-9-1; Filkins, 2010). The EU also hires routinely private security guards to protect its offices, civilian and police missions such as in the DR Congo and Afghanistan, and the UN employs armed PMSCs in over 40 percent of its operations (Krahmann \& Friesendorf, 2011a; Stoddard et al., 2008: 9). Together these examples demonstrate a significant change in practices that involve the increased use armed PMSCs in international conflict and stability operations.

\section{Responses to Norm Violation}

The responses of governments to the preceding developments provide further evidence for a transformation of the norm of the state monopoly on violence. This evidence pertains specifically to whether and to what degree the active participation of private contractors in fighting has been prosecuted, legally permitted or even praised. Arguably, the Geneva Conventions, the UN Mercenary Convention, the AU Mercenary Convention and national laws on foreign military recruitment which have institutionalized the norm against the international use of force by nonstate actors have not figured prominently in its enforcement due to their limited application or membership. Typically, norm violations have been penalized by charging mercenaries and other private armed forces with related crimes. In 1982, a South African court convicted Mike Hoare and six other men for airplane hijacking during an aborted coup attempt in the Seychelles (BBC, undated). In 2006, a French court found Bob Denard guilty of "belonging to a gang who conspired to commit a crime" after a failed fourth coup attempt in the Comoros in 1995 (BBC, 2006). In 2008 Simon Mann and collaborators were sentenced in Zimbabwe for buying and selling weapons for an attempt to overthrow the government in Equatorial Guinea (BBC, 2004).

The limited number of these cases and the leniency of their enforcement seem to suggest that the norm has not been particularly strong: Hoare was released in 1985, Denard never served for health reasons, and Mann was released in 2009 on humanitarian grounds. However, the frequency of national punishment of private armed forces such as pirates and mercenaries appears to be comparable to the enforcement of other international norms such as the norms against slave trade and terrorism (De Nevers, 2007). Moreover, France and the UK have been keen to deny claims by Denard and Mann that they acted with the tacit permission or at least knowledge of their home countries (Smit \& Berger, 2007; Brady \& Randall, 2009). This policy also applied to the UK's and South Africa's links with Sandline International and Executive Outcomes, the first incorporated PMSCs to engage in combat operations during the early 1990s. Allegations that the Foreign Office knew of Sandline International's involvement in Sierra Leone forced the British government to think about its role in controlling such firms, and Executive Outcome led South Africa "to approve a bill on 26 February 1998-Regulation of Foreign Military Assistance Actto limit the involvement of South African citizens in mercenary and related activities" (Francis, 1999: 321, 328). 
The USA's hire of armed guards to support its interventions in Iraq and Afghanistan marks a departure from these policies because it has involved a formal recognition of the legality of the use of armed force by PMSCs. Two developments illustrate this recognition. First, as mentioned above, the USA has explicitly authorized contractors to use deadly force for purposes other than self-defence, while simultaneously granting them immunity from local prosecution. The result has been a situation where DOD-employed PMCS are de facto permitted to engage in hostilities. Congressional investigations into the behaviour of Blackwater in Iraq observed that "employees had fired their weapons 195 times since early 2005 and in a vast majority of incidents used their weapons before taking any hostile fire" (Broder, 2007). In one instance, Blackwater defended the Coalition Provisional Authority headquarters in Iraq for several hours against Shiite militia (Priest, 2004; Wither, 2005: 116). Incident reports of PMSCs defending ISAF convoys in Afghanistan against "enemy action" unselfconsciously provide a "battle" damage assessment; a correct description for fights that in one, but by no means exceptional, case pitched 216 armed security guards against enemy insurgents (Wikileaks, 2009-10-4). Importantly, contracting governments have neither prosecuted private security guards for excessive use of force nor for direct participation in hostilities (Fainaru, 2007; Fainaru and al-Izzi, 2007; Leander, 2010). Even where contractors have killed innocent civilians, government promises of immunity and claims of selfdefense have impeded their prosecution (Risen, 2010).

Second, the USA has publicly praised the contribution of contractors to its military interventions by creating a special Defense of Freedom medal in 2001 to "honor civilian employees of the Department of Defense injured or killed in the line of duty" (DOD, 2001). The medal serves as a civilian equivalent to the armed forces' Purple Heart Medal, publicly reinforcing the image that US contractors legitimately participate in conflicts and can be considered equal in status to national soldiers.

Also the UK and Canada have presented military campaign medals to contractors deployed with their armed forces in Iraq. In recognition of the centrality of their efforts in operation TELIC no less than 335 contractors received the UK Ministry of Defence Iraq Medal (Hansard, 2006: Col.W300-W303), and the Canadian forces had awarded medals to several contractors for their efforts "in the presence of an armed enemy" (cited in: Spearin, 2008/9: 485; also Murray, 2006).

Most US allies have been less explicit in their endorsement of the private use of armed force in military interventions. The UK, Germany and Netherlands neither permit the use of violence beyond self-defence, nor do they generally exempt contractors from local jurisdiction. ${ }^{4}$ In sum, the responses of the USA and some of its leading allies in Europe towards the private use of violence in international affairs have evolved significantly over the past decade. At the heart of this transformation is the acceptance of PMSCs as legal and legitimate actors.

\section{Changes in Laws and Regulations}

While the USA and some of its European allies increasingly tolerate or accept of the use of armed force by PMSCS, they have simultaneously attempted to increase governmental control of these companies through new or increased regulation. In the USA, a number of high profile cases such as the Blackwater Nisour Square massacre have led to efforts to expand national laws to PMSCs working for US agencies abroad. These laws have included the Military Extraterritorial Jurisdiction Act (MEJA) of 2000 and the MEJA Expansion and Enforcement Act of 2007 which apply US criminal law to DOD contractors abroad, and the amended Uniform Code of Military Justice (UCMJ) which extends military law to civilian contractors employed in conflict situations. 
In 2011, the DOD has tightened its internal regulations on the use of PMSCs in DOD Instruction 3020.41 "Operational Contract Support", and the rule "U.S. Government Private Security Contractors Operating in a Contingency Operations, Combat Operations or Other Significant Military Operations" has set out detailed requirements for "the selection, accountability, training, equipping, and conduct of personnel performing private security functions" to other government agencies (CENTCOM, 2012).

In Europe there have been fewer efforts to increase governmental or legal control over armed security contractors that operate internationally because of the absence of major scandals. The UK, for instance, asserts that "No complaint or reports of human rights abuses have been received in connection to the activities of private security companies contracted by the MOD in the last five years" (Hansard, 2009a). In 2010, the UK thus decided to opt for a self-regulation of international PMSCs registered in the country (FCO, 2010). The Germany parliament has proposed several times new regulations, but the government has also seen no pressing need to act as there are very few German PMSCs that operate abroad (Bundestag, 2008; Bundestag, 2010).

Recently, however, a major shift has occurred in the policies of some European countries in the context of maritime piracy. Due to the persistent threat of attacks in the Gulf of Aden, the governments of Spain, Denmark, Germany, Norway, Italy and the UK have legally allowed, officially endorsed and/or publicly subsidized armed PMSCs hired to defend maritime vessels against pirates (Skuld, 2012). The US Coast Guard Maritime Security Directive 104-6 even requires owners to "supplement ships with armed or unarmed security based on a piracy-specific vessel threat assessment conducted by the operator and approved by the Coast Guard" (House, 2009). Although such action cannot be regarded as direct participation in hostilities, the permission to use private violence against pirates represents a radical turnabout after the twentieth century had seen the legal or effective elimination of weapons on board of ships (Liss, 2012). Since these PMSCs are hired by private actors rather than government agencies, there has been political pressure to ensure appropriate legal controls. Like the USA, several European governments have adopted new laws and regulations for the private use of armed force by maritime PMSCs. Spain passed Decree 1628 on 30 October 2009 that permits ships owners to contract adequately armed PMSCs (Bürgin, 2012). In 2011, Norway amended its regulation of protective measures on board ships to authorize the use of force "When necessary to prevent or protect against acts of terrorism and piracy" although Norway's 2009 Security Guards Services Act at the same time prohibits the use of arms by Norwegian PMSCs on land (Østensen, 2012; Skuld, 2012). In summer 2012, the German government passed a draft that will create a licensing system for maritime PMSCs and allow armed security guards to use light and semi-automatic weapons to protect ships in international waters (BMWi, 2012).

Even at the international level, the Montreux Document and the UN Draft Document on PMSCs further support the emergence of new codes of conduct for the use of PMSCs in international affairs. In sum, there is growing evidence for the emergence of national and international promulgations of a norm that permits the private use of armed force by PMSCs in a limited, but variously defined, set of circumstances.

\section{Discourses on the State Monopoly on Violence}

The preceding practical and legal developments have been justified by a discourse that illustrates a changing interpretation of the state monopoly on the legitimate use of violence. In the USA and Europe, this discourse has been characterised by two elements. The first element has been an 
increasingly restrictive interpretation of the state monopoly on violence through the narrowing of the functions considered to be 'inherently governmental'. Until the mid-1990s the inherent functions of state agencies, including the armed forces, were defined in the USA as all tasks that "represent the exercise of sovereign power" (Commission on Roles and Missions of the Armed Forces, 1995, p.3-3). They included the direct use of armed force for national and international defence such as a Congressional prohibition against the use of contract security guards at domestic military installations (GAO, 2006: 6). During the next decade the range of these functions was progressively cut down. Today, the governmental discourses in the USA, the UK and Germany argue that the state monopoly on violence refers to the control over the legitimate use of armed force, not its actual exercise (CENTCOM, 2012; Hansard, 2009b; Bundestag, 2009). As the UK government asserts, "There is an important and legitimate role for the private sector in providing security in post-conflict situations, such as in Iraq and Afghanistan" (Hansard, 2004). Accordingly, the use of armed force by private contractors does not affect the monopoly on violence as long as a national government is the contracting party or able to regulate the ways in which private force is deployed (Patterson, 2010: 218).

The second element of this discourse has been the distinctions between offensive and defensive security services. Its central argument is that PMSCs do not fall under the legal prohibitions against mercenaries because they do not fit the definition entailed in the UN, AU and Geneva conventions (Krahmann, 2012). According to this definition mercenaries are specially recruited to fight in an armed conflict, take direct part in the hostilities and are not sent by a party to the conflict (Geneva Conventions, 1977). As the preceding sections have illustrated, the praxis is more ambiguous. The ICRC (2009: 38) acknowledges, "the line between the defence of military personnel and other military objectives against enemy attacks (direct participation in hostilities) and the protection of those same persons and objects against crime or violence unrelated to the hostilities (law enforcement / defence of self or others) may be thin". The USA has therefore adopted an increasingly narrow definition of 'direct participation in hostilities' which pertains only to offensive action. Quarterly Reports on US contractors issued by the US Central Command (CENTCOM) emphasize that "Private security contractor personnel are not authorized to participate in offensive operations". Moreover, the reports highlight that DOD contractors are under the direct control of the US government and "must comply with specific USCENTCOM Rules for the Use of Force (RUF)" (CENTCOM, 2012). Other governments that hire armed security contractors have used a similar strategy. Spearin (2008/9: 485-6; see also Perry, 2008/9: 693) notes that Canada's "forces' "core" activities are being reinterpreted to involve combat, rather than just the general use and management of armed force per se". The NATO Logistics Handbook illustrates the proliferation of this view among US allies by stating that "Contractor support is not applicable to combat functions", but listing a wide range of services that may be provided by PMSCs in support of NATO missions (NATO, 2007: 104) Indeed, NATO has itself employed armed security guards to protect its logistics convoys against enemy attacks in Afghanistan.

The discursive reinterpretation of the core functions of the state and the military, and the differentiation between mercenaries who fight in 'combat' and PMSCs who engage in 'defensive operations' thus helps to explain how the norm of the state monopoly on violence can change, while at the same time the norm against mercenarism has remained strong (Percy, 2007b). 


\section{Conclusion}

The norm of the state monopoly on the legitimate use of armed force remains a key reference point national and international law as well as political discourses. However, the understanding of this norm is currently undergoing significant change. During the twentieth century the norm was widely interpreted as prohibiting the use of armed force by non-state actors in the international arena. Today a growing number of governments consider the norm to be limited to offensive combat operations. The belief that states are able to control the international use of force by private contractors through contracts or national regulations has also contributed to the reinterpretation of the norm of the state monopoly on violence. The emerging contemporary understanding of the norm thus resembles its meaning between 1600 and 1800 when governments and rulers sought to manage the private use of armed force through governmental authorizations.

The international extension and strength of this revised understanding of the norm are more difficult to determine. In terms of the stages of norm evolution, it seems that the transformation of the norm has already surpassed its 'norm emergence' stage in which the USA has acted, intentionally or unintentionally, as a norm entrepreneur by setting important precedents for the use of armed PMSCs in international interventions and by adopting new laws and regulations that have promulgated its new understanding of the norm as limited to offensive action. Significant evidence for a 'norm cascade' can be identified among many of its allies such as the UK, Canada, the Netherlands, Germany, Italy, Spain and Norway who have started to permit the international use of force by PMSCs even when hired by private actors such as against pirate attacks. For a norm cascade speaks also the observation that the international community has not regarded the use of armed force PMSCs in places such as Iraq and Afghanistan as mercenary activity, but that even international organizations such as NATO, the EU and UN are deploying PMSCs for military and civilian force protection. The failure of the international community to agree on a global regulation of PMSCs puts into question whether the evolution of the norm towards an inclusion of state-sanctioned or regulated private armed force has already reached the phase of international 'norm internalization'. However, the international negotiations leading up to the Montreux Documents illustrate that the development of the norm of the state monopoly on violence has arrived at a pivotal juncture which, if existing trends continue, may set the legal conditions for a return of private armed forces in international affairs.

\section{Funding}

The author gratefully acknowledges funding for this research from the Alexander von Humboldt Foundation and the Peace Research Institute Frankfurt (PRIF).

\section{Notes}

\footnotetext{
${ }^{1}$ Blackwater does not exist under this name anymore. It was first renamed Xe Services after the Nisour Square incident. In 2011 it changed its name again to Academi.

2 The states included Afghanistan, Angola, Australia, Austria, Canada, China, France, Germany, Iraq, Poland, Sierra Leone, South Africa, Sweden, Switzerland, Ukraine, the United Kingdom and the United States. Since then another 22 states have joined the declaration. See http://www.eda.admin.ch/eda/en/home/topics/intla/humlaw/pse/parsta.html.

3 US CENTCOM, Quarterly Reports, available at: http://www.acq.osd.mil/log/PS/CENTCOM_reports.html. Between 2008-2011 the figures refer to armed contractors, while from 2011 CENTCOM has stopped distinguishing between armed and unarmed 'security contractors'. However, according to Schwartz (2011: 2 ), armed personnel make up $90 \%$ or more of US security contractors.

4 The UK grants immunity to security guards working for diplomatic missions abroad. However, this immunity has so far never been invoked (Hansard, 2010).
} 


\section{References}

Adams, Thomas K., 1999. 'The New Mercenaries and the Privatization of Conflict', Parameters 29(2): 103-116.

Advisory Council on International Affairs (AIV), 2007. 'Employing Private Military Companies: A Question of Responsibility', No. 59, December. The Hague: AIV.

Anderson, Elisabeth, 2000. 'Beyond Homo Economicus: New Developments in Theories of Social Norms', Philosophy and Public Affairs 29(2): 170-200.

Avant, Deborah D., 2005. The Market for Force: The Consequences of Privatizing Security. Cambridge: Cambridge University Press.

Axelrod, Robert, 1986. 'An Evolutionary Approach to Norms', American Political Science Review 80(4): 1095-1111.

Bailes, Alison, Ulrich Schneckener \& Herbart Wulf, 2007. 'Revising the State Monopoly on the Legitimate Use of Force' DCAF Policy Paper No. 24. Geneva: DCAF.

Barkin, J. Samuel \& Bruce Cronin, 1994. 'The State and the Nation: Changing Norms and the Rules of Sovereignty in International Relations', International Organization 48(1): 107-130.

BBC, undated. On this Day, 1982: Seychelles Coup Leader Guilty of Hijack, available at: http://news.bbc.co.uk/onthisday/hi/dates/stories/july/27/newsid_2499000/2499153.stm.

BBC, 2001. 'Peacekeeping 'Role' for Mercenaries', 13 February.

BBC, 2004. 'Zimbabwe Jails UK 'Coup Plotter', 10 September.

BBC, 2006. 'French 'Dog of War' Spared Jail', 20 June.

Björkdahl, Annika, 2002. 'Norms in International Relations: Some Conceptual and Methodological Reflections', Cambridge Review of International Affairs 15(1): 9-23.

Boyd, Robert \& Peter J. Richerson, 1994. 'The Evolution of Norms: An Anthropological View', Journal of Institutional and Theoretical Economics 150(1): 72-87.

Brady, Brian, \& David Randall, 2009. 'Foreign Office Warns Mann to 'Keep Quiet',' The Independent on Sunday, 8 November.

Broder, John M., 2007. 'Chief of Blackwater Defends His Employees', New York Times, 3 October.

Bürgin, Annina, 2012. 'Private Security Companies in Maritime Affairs: The Spanish Maritime Security Governance', Unpublished paper, ECPR Joint Sessions Workshop, Antwerp.

Bundesministerium für Wirtschaft und Technologie (BMWi), 2012. Kabinett beschließt Gesetzentwurf zur Zulassung privater Sicherheitskräfte zur Pirateriebekämpfung, Press Release, 18 July, available at: http://www.bmwi.de/DE/Presse/pressemitteilungen,did=499738.html.

Bundestag, 2008. 'Antrag der Abgeordneten Dr. Karl-Theodor Freiherr zu Guttenberg et al. und der Fraktion der SPD, Nichtstaatliche militärische Sicherheitsunternehmen kontrollieren,' 16. Wahlperiode, Drucksache 16/10846, 12 November.

Bundestag, 2009. 'Beschlussempfehlung und Bericht des Auswärtigen Ausschusses, Nichtstaatliche militärische Sicherheitsunternehmen kontrollieren,' 16. Wahlperiode, Drucksache 16/12479, 26 March.

Bundestag, 2010. 'Antrag der Fraktion der SPD, Nichtstaatliche militärische Sicherheitsunternehmen registrieren und kontrollieren,' 17. Wahlperiode, Drucksache 17/4198, 15 December.

Central Command (CENTCOM), 2012. Contractor Support of U.S. Operations in the CENTCOM Area of Responsibility to Include Iraq and Afghanistan, April, available at: http://www.acq.osd.mil/log/PS/CENTCOM_reports.html.

Chesterman, Simon \& Chia Lehnardt, eds, 2007. From Mercenaries to Market: The Rise and Regulation of Private Military Companies. Oxford: Oxford University Press. 
Cleaver, Gerry, 2000. 'Subcontracting Military Power: The Privatisation of Security in Contemporary sub-Saharan Africa', Crime Law and Social Change 33(1-2): 131-49.

Cockayne, James, 2008. 'Regulating Private Military and Security Companies: The Content, Negotiation, Weaknesses and Promise of the Montreux Document', Journal of Conflict \& Security Law 13(3): 401-428.

Commission on Roles and Missions of the Armed Forces, 1995. Directions for Defense. Washington, D.C.: Department of Defense.

Cortell, Andrew P. \& James W. Davis, Jr., 1996. 'How Do International Institutions Matter? The Domestic Impact of International Rules and Norms', International Studies Quarterly 40(4): 451-78.

De Nevers, Renee, 2007. 'Imposing International Norms: Great Powers and Norm Enforcement,' International Studies Review 9(1): 53-80.

Department of Defense (DOD), 2006. Contractor Personnel Authorized to Accompany US Armed Forces (DFARS Case 2005-D013), Interim Rule, in Federal Register 71.

DOD, 2009. 'Defense Federal Acquisition Regulation Supplement (DFARS)', available at: http://www.acq.osd.mil/dpap/dars/dfarspgi/current/index.html.

DOD, 2001. 'Defense of Freedom Medal Unveiled', News Release, 27 September, available at: http://www.defense.gov/releases/release.aspx?releaseid=3068

Etzioni, Amitai, 2000. 'Social Norms: Internationalization, Persuasion, and History', Law \& Society Review 34(1): 157-178.

Fainaru, Steve, 2007. 'Iraq Contractors Face Growing Parallel War', Washington Post, 16 June.

Fainaru, Steve, \& Saad al-Izzi, 2007. 'U.S. Security Contractors Open Fire in Baghdad', Washington Post, 27 May.

Foreign and Commonwealth Office (FCO), 2010. Private Military and Security Companies (PMSCs): Summary of Public Consultation Working Group, April, available at: http://www.fco.gov.uk/resources/en/pdf/about-us/our-publications/pmsc-working-groupsummary-060410.

Filkins, Dexter, 2010. 'Convoy Guards in Afghanistan Face Enquiry', New York Times, 6 June.

Filkins, Dexter \& Scott Shane, 2010. 'Afghan Leader Sees Plan to Ban Private Guards', New York Times, 16 August.

Finabel, 2008. Possibilities and Limitations of the Operational Co-operation with Private "Military" Companies (PMC), A.24.R, Brussels, 8 July.

Finnemore, Martha \& Kathryn Sikkink, 1998. 'International Norm Dynamics and Political Change', International Organization 52(4): 887-917.

Fitzsimmons, Scott, 2009. 'A Rational-constructivist Explanation for the Evolution and Decline of the Norm against Mercenarism', Journal of Military and Strategic Studies 11(4): 1-32.

Florini, Ann, 1996. 'The Evolution of International Norms', International Studies Quarterly 40(3): 363-389.

Francis, David J., 1999. 'Mercenary Intervention in Sierra Leone: Providing National Security or International Exploitation?' Third World Quarterly 20(2): 319-38.

Geneva Conventions, 1977. 'Additional Protocol I', available at: http://www.icrc.org/eng/war-andlaw/treaties-customary-law/geneva-conventions/index.jsp.

Goertz, Gary \& Paul F. Diehl, 1992. 'Toward a Theory of International Norms: Some Conceptual and Measurement Issues', Journal of Conflict Resolution 36(4): 634-664.

GAO, 2006. Contract Security Guards: Army's Guard Program Requires Greater Oversight and Reassessment of Acquisition Approach, GAO-06-284. Washington, D.C.: GAO. 
House Committee on Transportation and Infrastructure, Subcommittee on Coast Guard and Maritime Transportation (House), 2009. 'Hearing on Piracy against U.S.-Flagged Vessels: Lessons Learned', 20 May.

Hansard, 2010. 'Foreign and Commonwealth Office - Afghanistan: Peacekeeping Operations,' Written Answers, Vol. 514, Session 2010-11, 26 July, Column 672W.

Hansard, 2009a. 'Security Companies', Written Answers, Vol. 502, Session, 2009-10, 16 December, Column 1218W.

Hansard, 2009b. 'Afghanistan and Iraq: Peacekeeping Operations,' Written Answers, Vol. 486, Session 2008-9, 19 January, Column 353W.

Hansard, 2006. 'Iraq Service Medal', Written Answers, Vol. 446, Session 2005-6, 10 May, Columns W300-W303.

Hansard, 2004. 'Private Military Companies,' Written Answers, Vol. 424, Session 2003-4, 15 September.

Hollis, Martin \& Steve Smith, 1990. Explaining and Understanding. Oxford: Clarendon Press.

Howe, Herbert M., 1998. 'Private Security Forces and African Stability: The Case of Executive Outcomes', Journal of Modern African Studies 36(2): 307-31.

International Committee of the Red Cross (ICRC), 2009. Interpretive Guidance on the Notion of Direct Participation in Hostilities under International Humanitarian Law. Geneva: ICRC, available at: http://www.icrc.org/eng/assets/files/other/icrc_002_0990.pdf.

Isenberg, David, 2008. Shadow Force: Private Security Contractors in Iraq. Westport: Praeger.

Kacowicz, Arie M., 2005. The Impact of Norms in International Society: The Latin American Experience, 1881-2001. Notre Dame: University of Notre Dame Press.

Klotz, Audie, 1995. 'Norms Reconstituting Interests: Global Racial Equality and U.S. Sanctions against South Africa', International Organizations 49(3): 451-78.

Klotz, Audie, 1996. 'Norms and Sanctions: Lessons from the Socialization of South Africa', Review of International Studies 22(2): 173-190.

Krahmann, Elke, 2010. States, Citizens and the Privatization of Security. Cambridge: Cambridge University Press.

Krahmann, Elke, 2012. 'From 'Mercenaries' to 'Private Security Contractors': The (Re)construction of Armed Security Providers in International Legal Discourses,' Millennium 40(2): 339-359.

Krahmann, Elke \& Cornelius Friesendorf, 2011a. The Role of Private Security Companies (PSCS) in CSDP Missions and Operations. Brussels: European Parliament.

Krahmann, Elke \& Cornelius Friesendorf, 2011b, Debatte vertagt? Militär- und Sicherheitsfirmen in deutschen Auslandseinsätzen. HSFK Report No. 8/2011, Frankfurt: HSFK.

Krasner, Stephen D., 1982. 'Structural Causes and Regime Consequences: Regimes as Intervening Variables', International Organization 36(2): 185-205.

Leander, Anna, 2010. 'The Paradoxical Impunity of Private Military Companies: Authority and the Limits of Accountability', Security Dialogue 41(5): 467-490.

Leander, Anna, 2006. Eroding State Authority? Private Military Companies and the Legitimate Use of Force. Rome: Centro Militare di Studi Strategici.

Leander, Anna, ed., 2012 forthcoming. Commercializing Security in Europe: The Consequences for Peace and Reconciliation Strategies. London: Routledge.

Leibfried, Stefan \& Kerstin Martens, Peter Mayer, Achim Hurrelmann, eds, 2008. Transforming the Golden-Age Nation State. London: Palgrave.

Liss, Carolin, 2012. 'Papertigers, Mercenaries and Negligent States: The Rise of Maritime PMSCs and (International) Maritime Security Governance', Unpublished paper, ECPR Joint Sessions Workshop, Antwerp. 
Moore, Dene, 2010. 'Canadian Forces to Review Nine Private Security Contracts on Afghan Ban', The Globe and Mail, 18 August.

Murray, Ben, 2006. 'American, British Contractors Honored for Work in Iraq', Stars and Stripes, 28 June.

Nadelmann, Ethan A., 1990. 'Global Prohibition Regimes: The Evolution of Norms in International Society', International Organization 44(4): 479-526.

NATO, 2007. NATO Logistics Handbook, available at: www.nato.int/docu/logien/logistics_hndbk_2007-en.pdf.

Nossal, Kim Richard, 2001. 'Global Governance and National Interest: Regulating Transnational Security Corporations in the Post-Cold War Era', Melbourne Journal of International Law 2(2): 459-476.

Østensen, Åse G., 2012. 'Who Governs Private Security on the High Seas? Norway's Regulation of the Use of Armed Guards to Counter Piracy', Unpublished paper, ECPR Joint Sessions Workshop, Antwerp.

Opello, Walter C., Jr. \& Stephen J. Rosow, 2004. The Nation-State and Global Order: A Historical Introduction to Contemporary Politics. Boulder, Col.: Lynne Rienner.

Ortiz, Carlos, 2010. Private Armed Forces and Global Security. Santa Barbara, Cal.: Praeger.

Paluck, Elizabeth Levy, 2009. 'What's in a Norm? Sources and Processes of Norm Change', Journal of Personality and Social Psychology 96(3): 594-600.

Patterson, Malcolm, 2010. 'A Corporate Alternative to United Nations ad hoc Military Deployments', Journal of Conflict \& Security Law 13(2): 215-232.

Payne, Rodger A., 2001. 'Persuasion, Frames and Norm Construction', European Journal of International Relations 7(1): 37-61.

Percy, Sarah, 2007a. Mercenaries: The History of a Norm in International Relations. Oxford: Oxford University Press.

Percy, Sarah, 2007b. 'Mercenaries: Strong Norm, Weak Law', International Organization 61(2): 367397.

Petersohn, Ulrich \& Diana Panke, 2012. 'Why International Norms Disappear Sometimes', European Journal of International Relations forthcoming, available at Online First.

Posner, Richard A. \& Eric B. Rasmusen, 1999. 'Creating and Enforcing Norms, with Special Reference to Sanctions', International Review of Law and Economics 19(3): 369-382.

Price, Richard, 2003. 'Transnational Civil Society and Advocacy in World Politics', World Politics 55(4): 579-606.

Priest, Dana, 2004. 'Private Guards Repel Attack on U.S. Headquarters', Washington Post, 6 April.

Raymond, Gregory, 1997. 'Problems and Prospects in the Study of International Norms', Mershon International Studies Review 41(2): 205-245.

Risen, James, 2010. 'Efforts to Prosecute Blackwater Are Collapsing', New York Times, 20 October.

Sandholz, Wayne, 2008. 'Dynamics of International Norm Change: Rules against Wartime Plunder', European Journal of International Relations 14(1): 101-131.

Schwartz, Mosche, 2010. The Department of Defense's Use of Private Security Contractors in Iraq and Afghanistan: Background, Analysis, and Options for Congress. Washington, D.C.: Congressional Research Service.

Schwartz, Mosche, 2011. The Department of Defense's Use of Private Security Contractors in Iraq and Afghanistan: Background, Analysis, and Options for Congress. Washington, D.C.: Congressional Research Service.

Singer, Peter W., 2003. Corporate Warriors: The Rise of the Privatized Military Industry. Ithaca: Cornell University Press. 
Skuld, 2012. National Regulations on the Use of Private Guards, available at: http://www.skuld.com/Insight/Piracy/Armed-Guards/National-regulations-on-the-use-ofarmed-guards/.

Smit, Martina, \& Sebastien Berger, 2007. 'French Mercenary Bob Denard Dies Aged 78,' The Telegraph, 15 October.

Spearin, Christopher, 2008/9. "The Changing Forms and Utility of Force: The Impact of International Security Privatization on Canada', International Journal 64(2): 481-500.

Spruyt, Hendrik, 2000. 'The End of Empire and the Extension of the Westphalian System: The Normative Basis of the Modern State Order', International Studies Review 2(2): 65-92.

Stoddard, Abby, Adele Harmer \& Victoria DiDomenico, 2008. 'The Use of Private Security Providers and Services in Humanitarian Operations', Humanitarian Policy Group (HPG) Report 27. London: Overseas Development Institute.

Thomson, Janice E, 1990. 'State Practices, International Norms, and the Decline of Mercenarism', International Studies Quarterly 34(1): 23-47.

Thomson, Janice E., 1994. Mercenaries, Pirates and Sovereigns. Princeton: Princeton University Press.

United Nations $\quad(\mathrm{UN}), \quad$ Charter, $1945 . \quad$ available http://www.un.org/en/documents/charter/index.shtml.

UN, 2010. 'Report of the Working Group on the Use of Mercenaries as a Means of Violating Human Rights and Impeding the Exercise of the Right of Peoples to Self-Determination', A/HRC/15/25, 2 July, available at: http://www2.ohchr.org/english/issues/mercenaries/docs/A.HRC.15.25.pdf.

Weber, Max, 1994. Political Writings. Cambridge: Cambridge University Press.

Wither, James K., 2005. 'European Security and Private Military Companies: The Prospects for Privatized "Battlegroups"', Connections: The Quarterly Journal 4(2): 107-126.

Wulf, Herbert, 2007. 'Challenging the Weberian Concept of the State: The Future of the Monopoly on Violence,' The Austrialian Centre for Peace and Conflict Studies, Occasional Paper no. 9. University of Queensland, Australia.

Elke Krahmann is Professor of Security Studies at Brunel University. She has published widely on non-state actors and the commodification of security, with recent articles including 'Security: Collective Good or Commodity' in European Journal of International Relations, and 'Beck and Beyond: Selling Security in the World Risk Society' in Review of International Studies. She has received numerous research grants and awards for her research, including the Ernst-Otto Czempiel Prize for her monograph States, Citizens and the Privatization of Security (Cambridge University Press, 2010). A new collaborative ESRC-funded project with Anna Leander will examine the use of private security contractors by international organizations such as the United Nations, NATO and the European Union in military interventions. 